\title{
Voluntary adoption of non-local GAAP in the European Union: a study of determinants
}

Citation for published version (APA):

Cuijpers, R. J. R., Buijink, W. F. J., \& Maijoor, S. J. (2002). Voluntary adoption of non-local GAAP in the European Union: a study of determinants. METEOR, Maastricht University School of Business and Economics. METEOR Research Memorandum No. 069 https://doi.org/10.26481/umamet.2002069

Document status and date:

Published: 01/01/2002

DOI:

10.26481/umamet.2002069

Document Version:

Publisher's PDF, also known as Version of record

\section{Please check the document version of this publication:}

- A submitted manuscript is the version of the article upon submission and before peer-review. There can be important differences between the submitted version and the official published version of record.

People interested in the research are advised to contact the author for the final version of the publication, or visit the DOI to the publisher's website.

- The final author version and the galley proof are versions of the publication after peer review.

- The final published version features the final layout of the paper including the volume, issue and page numbers.

Link to publication

\footnotetext{
General rights rights.

- You may freely distribute the URL identifying the publication in the public portal. please follow below link for the End User Agreement:

www.umlib.nl/taverne-license

Take down policy

If you believe that this document breaches copyright please contact us at:

repository@maastrichtuniversity.nl

providing details and we will investigate your claim.
}

Copyright and moral rights for the publications made accessible in the public portal are retained by the authors and/or other copyright owners and it is a condition of accessing publications that users recognise and abide by the legal requirements associated with these

- Users may download and print one copy of any publication from the public portal for the purpose of private study or research.

- You may not further distribute the material or use it for any profit-making activity or commercial gain

If the publication is distributed under the terms of Article $25 \mathrm{fa}$ of the Dutch Copyright Act, indicated by the "Taverne" license above, 


\title{
Voluntary adoption of non-local GAAP in the European Union: a study of determinants
}

\author{
Rick Cuijpers* \\ Universiteit Maastricht \\ Willem Buijink \\ Katholieke Universiteit Brabant \\ Steven Maijoor \\ Universiteit Maastricht
}

\author{
Address for correspondence: \\ Universiteit Maastricht \\ Faculty of Economics and Business Administration \\ Department of Accounting and Information Management \\ PO Box 616 \\ 6200 MD Maastricht \\ The Netherlands \\ r.cuijpers@berfin.unimaas.nl
}

First draft: October 2001

This version: June 2002

* Corresponding author. Earlier versions of this paper were presented at Maastricht University and the $25^{\text {th }}$ annual congress of the European Accounting Association, 25-27 April 2002, in Copenhagen, Denmark. The authors would like to thank the session participants for their helpful comments and suggestions. The usual caveat applies. 


\title{
Voluntary adoption of non-local GAAP in the European Union: a study of determinants
}

\begin{abstract}
This study examines the determinants of voluntary adoption of non-local accounting principles for financial reporting (non-local GAAP) by non-financial companies listed and domiciled in the European Union. We restrict ourselves to the two most predominant internationally accepted sets of accounting standards: International Accounting Standards (IAS) and United States generally accepted accounting principles (US GAAP). The maintained hypothesis is that firms will switch from local to non-local GAAP if the benefits outweigh the costs. This study provides insight in the characteristics of firms that experience positive net-benefits from non-local GAAP adoption. Considering that mandatory adoption of IAS is envisaged for listed EU companies from 2005 on, the results are of potential interest to EU and national financial reporting regulators.

We have used various sources to identify EU companies that use non-local GAAP. The 1999 annual reports of all these companies were examined. We find that 133 nonfinancial companies in the EU voluntarily adopted non-local GAAP in 1999. This suggests that the net-benefits of using non-local GAAP are positive for only a small minority of EU companies.

Companies that do voluntarily use non-local GAAP are more likely to be listed on a US exchange, the EASDAQ exchange in Brussels, and have more geographically dispersed operations. Furthermore, they are more likely to be domiciled in a country with lower quality financial reporting and where IAS is explicitly allowed as an alternative to local GAAP.
\end{abstract}

Key Words: International accounting, Accounting standards, IAS, US GAAP, Voluntary adoption, European Union. 


\section{INTRODUCTION}

In recent years, economic and regulatory changes may have provided companies with incentives to voluntarily prepare their financial statements according to different accounting standards than those of their home country. Within the European Union (EU) important developments in this respect are the merger of several stock exchanges, initiatives at the International Organisation of Securities Commissions (IOSCO) and the International Accounting Standards Board (IASB), and the efforts of the Commission of the European Communities (European Commission, EC) to harmonise financial reporting.

This study investigates the extent of, and the factors associated with, voluntary adoption of non-local generally accepted accounting principles (GAAP) by non-financial companies domiciled and listed in the EU. We focus on voluntary adoption of International Accounting Standards (IAS) and United States (US) GAAP, the two most predominant internationally accepted sets of standards. The maintained hypothesis in this paper is that companies in the EU choose to report according to non-local GAAP if the benefits outweigh the costs associated with the switch from their local GAAP.

This study is the first to examine voluntary adoption of non-local GAAP in the EU as a whole. Identification of the characteristics of firms that are voluntarily reporting according to non-local GAAP is useful to regulatory bodies, like the EC and stock market regulators within the EU, considering the obligation for listed EU firms to start using IAS (or International Financial Reporting Standards, IFRS, as future standards by the IASB will be called) from 2005 on.

A central problem for a study such as this is to establish which companies fully adopt non-local GAAP. We use information from the IASB website, financial statement databases, and some other sources to identify listed EU companies using non-local GAAP in their 1999 fiscal year. We then inspect the notes and audit reports in the consolidated annual reports of 
all these companies to verify that they are stating compliance with IAS or US GAAP. This represents a major difference with some earlier studies. Ashbaugh (2001), for example, also includes companies that only provide footnote reconciliations to IAS or US GAAP. The firms that we study are making a much stronger commitment to report according to non-local GAAP by drawing up their entire financial statements in accordance with IAS or US GAAP.

We find that 133 non-financial companies domiciled and listed in the EU report according to IAS or US GAAP. This finding strongly suggests that by 1999/2000 most listed EU firms do not expect to benefit from switching to non-local accounting standards. Companies that do voluntarily adopt non-local GAAP are more likely to be listed on a US exchange, the EASDAQ exchange in Brussels, and have more geographically dispersed operations. Also, these companies are more likely to be domiciled in a country with lower quality financial reporting and where IAS is explicitly allowed as an alternative to local GAAP. We also analyse the choice between IAS and local GAAP (excluding US GAAP adopters) and find that the same factors also increase the probability of reporting according to IAS (excluding the effect of having a US exchange listing).

The remainder of this paper is organised as follows. The next section will provide a short background for this study, followed by a review of prior research and the development of hypotheses to be tested. In section 3 the data collection and research method used will be described. Results will be reported in section 4. The final section of the paper will contain a discussion of the findings and some concluding remarks.

\section{VOLUNTARY ADOPTION OF NON-LOCAL GAAP}

\section{Background}

Several developments may have motivated companies to prepare financial statements in accordance with non-local GAAP. Potentially the most important development is the rapid 
worldwide economic integration and the associated increase in cross-border capital flows. In the EU one recent manifestation of this phenomenon was the merger of three stock exchanges (Paris, Brussels, and Amsterdam). Other EU exchanges are also considering mergers. Also, the IOSCO has recommended its members to allow multinationals that are planning crossborder exchange listings to prepare their financial statements according to IAS (IOSCO, 2000). Already many stock market regulators allow (foreign) registrants to prepare their consolidated financial statements using non-local GAAP, sometimes with a requirement to provide a reconciliation to local GAAP. ${ }^{1}$ In the EU this is the case in most member states.

There were also some relevant developments on the regulatory side. In 1995 the EC recognised the need for further harmonisation of financial reporting in the EU going beyond the level achieved by the European Accounting Directives (EC, 1995). The EC expressed its support for IAS, the standards issued by the IASC (the International Accounting Standards Committee, the predecessor body to the IASB). In February 2001 the EC proposed a requirement for all EU domiciled companies listed on stock exchanges within the EU to prepare their financial statements in accordance with IAS by 2005 (EC, 2001b). The European Parliament and the Council adopted the regulation prepared by the EC in May 2002 (European Parliament and Council, 2002).

Until 2005 a company can voluntarily choose to adopt IAS or US GAAP for financial reporting. EU companies can do so in a number of ways. An extreme option is to provide two separate sets of financial statements: one using local GAAP (to satisfy regulatory requirements) and another one using non-local GAAP. A second possibility is to report according to a non-local set of accounting standards and provide a reconciliation to local GAAP. Third, companies in some EU countries have the option to comply with two sets of accounting standards by choosing certain accounting measurement options in local GAAP that are in accordance with non-local GAAP and providing additional disclosures that may be 
required under non-local GAAP. Finally, if allowed by the national (stock exchange) regulator, companies can provide financial statements that comply only with non-local GAAP. We classify companies that choose one of the four options described above, as complying with non-local GAAP. For the purposes of this paper, we do not consider preparing financial statements in accordance with local GAAP and providing a reconciliation to IAS or US GAAP as complying with non-local accounting standards.

\section{Previous research}

Recently, several empirical studies have been conducted on the determinants of the use of non-local GAAP, mainly IAS, for the preparation of financial statements. The hypotheses tested in these studies are derived from presumed incentives and disincentives - benefits and costs - of firms to switch from local to IAS or US GAAP.

El-Gazzar et al. (1999) compare 87 listed companies from various countries on the IASC list of 'Companies claiming to comply with IAS' with 87 matched companies using local GAAP. They find, using logit regression analysis, that disclosure of IAS financial statements is significantly positively related to the percentage of sales classified as foreign, the number of stock exchanges a firm is listed on, and being domiciled in a EU member state, and negatively related to the debt to equity ratio.

Dumontier and Raffournier (1998) investigate the reasons for voluntary compliance with IAS for Swiss listed companies. They find that the 51 firms using IAS in 1994 are larger, more internationally diversified, less capital intensive, and have more diffuse ownership than firms not using IAS.

Murphy (1999) compares 22 Swiss listed companies that had adopted IAS in 1994 with a matched sample of Swiss companies using local GAAP. She finds (using stepwise 
discriminant analysis) that companies that adopted IAS had a higher percentage of foreign sales and were listed on more stock exchanges.

Joos and Weets (2000) study the companies listed on the EASDAQ exchange in Brussels in 1999. These companies are obliged to either use IAS or US GAAP or, if they use their local GAAP, to provide a reconciliation to IAS or US GAAP. Joos and Weets examine the effect of factors associated with using IAS or US GAAP. They look at various size, performance, disclosure, and institutional variables. Using logistic regression analyses they find that non-exclusive EASDAQ IPO's and a dual listing on the NASDAQ exchange lead to usage of US GAAP. They also find that the auditor of the IPO prospectus influences the choice of accounting standards (companies hiring PWC are more likely to use IAS, whereas having Ernst \& Young, KPMG, or a non-Big 5 firm as an auditor increases the chances of using US GAAP). None of the other, size, performance, disclosure, or institutional variables appear to affect the choice of accounting standards.

Ashbaugh (2001) examines the accounting standard choices of 211 non-US/non-UK companies traded on the SEAQ market segment of the London stock exchange in 1993/94. These companies can use IAS, US, or local GAAP. She finds, using logit regression analysis, that companies adopting IAS or US GAAP instead of local GAAP have their shares traded in more foreign markets, are larger, and are more likely to have issued equity during the year. Also, there are more measurement and disclosure differences between IAS or US GAAP and their local GAAP.

Leuz and Verrecchia (2001) analyse the choice of accounting standards (IAS, US, or German GAAP) in 1998 for German companies included in the DAX 100 index. They use proxies for company size, financing needs, performance, and ownership dispersion as determinants of the choice between 'international' (IAS or US GAAP) and 'local' financial reporting as well as having a UK/US listing as a control variable. Using probit regression 
analysis they find that size, financing needs, and performance positively affect an 'international' reporting strategy.

Leuz (2001) investigates the choice of accounting policies of German companies (without a US listing) listed on the Neuer Markt ('New Market', NM) segment of the Frankfurt stock exchange in 1999 and 2000. The stock exchange regulations require that financial statements of companies listed on the NM comply with either IAS or US GAAP. Leuz finds, using probit regression analysis, that the characteristics of the firms adopting these GAAPs are largely similar. The only discriminating variable is relative size: US GAAP adopters were, on average, larger than IAS adopters.

In the context of this study a different stream of recent empirical research is also informative and important. Some authors have investigated the extent of compliance with IAS (Street et al., 1999; Street \& Bryant, 2000; Street \& Gray, 2001). In general, these papers find significant non-compliance with IAS. These results suggest that care in establishing IAS (and US GAAP) adoption is important. We therefore explain our procedure in detail in section 3 below.

\section{Hypotheses}

There is currently no EU regulator that mandates companies to use non-local accounting standards, except for the Deutsche Börse, which requires that companies that are traded on the Neuer Markt ('New Market') segment use either IAS or US GAAP. The EASDAQ (NASDAQ Europe) exchange in Brussels requires firms to fully adopt or prepare a reconciliation to either IAS or US GAAP. Adoption of non-local accounting standards is therefore voluntary for most companies. Our maintained hypothesis is that companies will switch from local to non-local GAAP if the benefits of its adoption outweigh the costs. 
Using IAS or US GAAP typically implies using stricter measurement rules and making more disclosures in financial statements than would be required under a firm's local GAAP (see also Ashbaugh, 2001). If a company therefore chooses to report according to IAS or US GAAP it is voluntarily making a commitment to providing more, and more standardised information to the capital markets.

The hypotheses that will be developed below are based on the studies discussed earlier and on the voluntary disclosure literature in general. All hypotheses will be stated in alternative form to indicate the expected relationship with the probability of voluntary nonlocal GAAP adoption.

\section{Stock exchange listings}

Firms with international stock exchange listings face additional capital market pressures (Meek et al., 1995) and stock exchange requirements (Cooke, 1992) that may lead them to increase their level of disclosure. Investors demand information about the domestic operating environment and domestic accounting regulations of foreign listed companies (Nobes \& Parker, 1998). Also, firms will incur costs to comply with the regulations of the different stock exchanges that they decide to list on (Biddle \& Saudagaran, 1991), and as Saudagaran and Biddle (1995) point out: 'these costs can be significant'. In order to comply with these regulations, firms may be motivated to report according to an internationally accepted set of accounting principles. In fact, many stock exchanges around the world allow foreign registrants to prepare their financial statements according to IAS or US GAAP. Prior studies have shown that the level of disclosure (Cooke, 1992; Meek et al., 1995) or the probability of using non-local GAAP (see above, El-Gazzar et al.; 1999; Murphy, 1999; Ashbaugh, 2001) is positively associated with the number of foreign stock exchange listings of a company. 
We expect the incentives to switch to non-local GAAP to be higher for companies listed outside the EU, because within the EU there is a mutual recognition of each member states' accounting standards (Fédération des Experts Comptables Européens, 1993). This means that EU companies listing on a EU stock exchange can use their local GAAP to draw up their financial statements. However, we even expect companies with multiple EU exchange listings only to have more incentives to adopt non-local GAAP.

$H_{l a}$ : The probability of using non-local GAAP is positively associated with the number of EU stock exchange listings of a firm.

$H_{l b}$ : The probability of using non-local GAAP is positively associated with the number of non-EU stock exchange listings of a firm.

Companies listed on one of the exchanges in the United States will have to provide a reconciliation to US GAAP if they do not fully apply US GAAP. For this group of companies the benefits of US GAAP adoption are likely to be larger than for companies without a US listing. We therefore expect companies listed in the US to be more likely to report according to non-local instead of local GAAP.

$H_{l c}$ : The probability of using non-local GAAP is positively associated with a listing in the United States.

The Neuer Markt (NM), the 'new market' segment of the Deutsche Börse, obliges companies to use either IAS or US GAAP. Because companies traded on the NM are constrained in their choice of GAAP (they do not voluntarily choose to report according to 
non-local GAAP), they will be excluded from the analyses. The EASDAQ exchange obliges companies to fully adopt IAS or US GAAP, or to provide a reconciliation to either set of GAAP. While companies are still free to choose, the requirements of EASDAQ bias the choice between local and non-local GAAP. Companies listed on the EASDAQ exchange will benefit more from using non-local GAAP because they would not have to prepare a reconciliation anymore. We therefore expect companies traded on EASDAQ exchange to be more likely to report according to non-local GAAP.

$H_{l d}$ : The probability of using non-local GAAP is positively associated with a listing on the EASDAQ exchange.

\section{International operations}

Companies operating internationally have a much more heterogeneous group of stakeholders than companies that mainly operate nationally. In order to provide standardised information to these different groups, we expect firms operating on an international scale to be more likely to adopt non-local GAAP. The previous set of hypotheses focuses only on information demands from international shareholders, but ignores other stakeholders, like foreign governments, customers, and suppliers.

$H_{2}$ : The probability of using non-local GAAP is positively related to the extent of international operations of a company.

\section{Country-specific factors}

Ashbaugh (2001) states that it is reasonable to conjecture that firms incur differential costs to disclose internationalised financial information. Companies from countries with accounting 
policies quite similar to IAS or US GAAP incur less switching costs, because compliance is often possible by choosing accounting methods that satisfy both sets of GAAP. The same argument can be made for companies from countries were accounting regulation is very flexible. Companies from these countries can use this latitude to satisfy both local and nonlocal GAAP (Ashbaugh \& Pincus, 2001).

Besides costs, the benefits of switching to non-local GAAP also partly depend on the accounting environment in a company's home country. Companies from countries with accounting standards of lower quality that want to provide high quality accounting information, can use IAS or US GAAP as a signal of their commitment to higher quality financial reporting. Firms from countries with high quality accounting standards will be less inclined to switch to non-local GAAP, because by reporting according to their local accounting standards they are already providing financial information of high quality.

One way to measure the quality of financial reporting in different countries is to look at the value relevance of accounting earnings. Ali and Hwang (2000) conclude that the value relevance of accounting data differs across countries. Reported profits in countries with a market-oriented as opposed to a bank-oriented financial system, for example, are more value relevant. ${ }^{2}$ The benefits of switching from local to non-local GAAP for companies domiciled in countries with highly value-relevant financial accounting, like the United Kingdom and The Netherlands, will therefore be less than for companies from countries where financial accounting is much less value relevant, like Germany or France.

Ashbaugh (2001) develops a measure of the differences between IAS or US GAAP and a firm's local GAAP, based on a number of disclosure and measurement issues. The resulting score reflects the difference in required disclosures and the number of accounting measurement constraints under non-local GAAP relative to a firm's domestic GAAP. Ashbaugh (2001) finds that this score is positively associated with the adoption of non-local 
GAAP, suggesting that companies from countries where accounting regulations differ more from IAS or US GAAP are more frequently using non-local accounting standards to draw up their financial statements. Also, Ashbaugh and Pincus (2001) find that analyst forecast accuracy improves relatively more after IAS adoption for firms from countries with accounting standards that differ more from IAS.

La Porta et al. (1998) use a score published by the CIFAR (Center for International Financial Analysis and Research) that measures the quality of a country's financial reporting. We also use the CIFAR-score and expect the quality of financial reporting in a firm's country of domicile to be negatively related to the likelihood of non-local GAAP adoption. Companies from countries with high quality financial reporting are expected to be less likely to switch to non-local GAAP, and vice versa.

$H_{3 a}: \quad$ The probability of using non-local GAAP is higher for companies from countries with lower quality accounting standards.

In some EU members states usage of IAS is explicitly allowed as an alternative to using local accounting standards for consolidated financial reporting. This is the case in Germany, Austria, Belgium, France, Luxembourg, Finland, and Italy (EC, 2001a). It is easier for companies from these seven countries to switch to non-local GAAP, because they will not face any reconciliation requirements. We therefore expect usage of non-local GAAP to be higher in these countries.

$H_{3 b}$ : The probability of using non-local GAAP is higher for companies from countries where IAS is explicitly allowed as an alternative to local GAAP. 


\section{Corporate governance}

Public disclosures of companies can be expected to reflect their governance structure. Firms with many 'inside' stakeholders have fewer incentives to disclose high quality financial information than firms that rely primarily on 'outsiders' to provide the necessary capital. This is because 'insiders' to the company are not dependent on public disclosures, whereas for firms with many outside stakeholders, public disclosures are the only economically feasible form of communication. The use of a high-quality set of GAAP, targeted at the interests of equity investors, like IAS or US GAAP, is therefore expected to be higher for companies with many outside stakeholders. This study measures the 'inside' or 'outside' orientation of a company in two ways: (1) the percentage of debt in a company's capital structure and (2) a measure of stock ownership concentration.

Previous studies on voluntary disclosure have often used a firm's capital structure as a proxy for their governance structure (Chow \& Wong-Boren, 1987; Meek et al., 1995; Zarzeski, 1996; Jaggi \& Low, 2000). Different authors however, hypothesise different relationships between capital structure and disclosure. Meek et al. (1995) argue that voluntary disclosures can be expected to increase with leverage, because in firms with proportionally more debt, the potential wealth transfers from debt holders to stockholders and managers (agency costs) are larger. Zarzeski (1996) expects to find a negative relationship between disclosure and leverage, assuming that companies with high debt ratios are located in countries with strong banking relationships and many interlocking corporate ownerships (a bank-oriented financial system). In these countries there is less need for high quality financial reporting, as many stakeholders are 'insiders' to the firm and rely on private rather than public information to make decisions. These two different lines of reasoning illustrate the inability of leverage alone to be a good proxy for the governance structure of a company. 
We assume that leverage measures the governance structure of a firm, because equity investors are usually 'outsiders' to the firm, whereas providers of debt finance, such as banks, are less dependent on public disclosures of companies. However, this argument does not take the existence of public debt into account. In addition to leverage, we use concentration of stock ownership as a proxy for the governance structure of a company. Equity investors owning a large stake in a firm are assumed to be less dependent on public disclosures and focus more on other information sources. We expect these two proxies for the governance structure (leverage and concentration of stock ownership) to be negatively related to nonlocal GAAP adoption because they both proxy for the 'inside' ownership of a firm.

$H_{4 a}$ : The probability of using non-local GAAP is negatively related to the leverage of a firm.

$H_{4 b}: \quad$ The probability of using non-local GAAP is negatively related to the concentration of ownership of a firm.

Size

Voluntary disclosure research has consistently found that larger firms provide stakeholders with more disclosures (Chow \& Wong-Boren, 1987; Cooke, 1992; Lang \& Lundholm, 1993; Meek et al., 1995; Zarzeski, 1996; Ashbaugh, 2001; Jaggi \& Low, 2000). It is however unclear what factors the size variable is actually representing. Costs of disclosure appear to be decreasing in firm size. One component of disclosure costs is information production costs, for which the fixed component can be spread over more 'units of size' in large organisations (Foster, 1986; Lang \& Lundholm, 1993). Also, since larger firms generally have higher levels of analyst following, information dissemination (Lang \& Lundholm, 1993) 
and competitive disadvantage costs (Foster, 1986) are reduced. Higher political costs, caused by higher public exposure, and agency costs, caused by more widely dispersed ownership, may also drive larger firms to voluntarily make more disclosures (Foster, 1986; Meek et al., 1995). Furthermore, voluntary disclosure is expected to decrease transaction and litigation costs (Lang \& Lundholm, 1993). We also expect this positive relation to hold with respect to the choice to use non-local GAAP, because it represents a commitment to making more disclosures than would typically be required under local GAAP.

Because of the consistency of the previous results, the following hypothesis is unidirectional.

$H_{5}$ : The probability of using non-local GAAP is positively related to the size of a firm.

\section{Industry}

Competitive pressures or industry-specific regulation (Cooke, 1992) may cause the level of voluntary disclosure to differ between industries. Cooke (1992) finds, for his sample of Japanese companies, that manufacturing firms voluntarily disclose more information than non-manufacturing firms. Meek et al. (1995) hypothesise that proprietary costs may differ across industries. They find evidence of an industry effect for voluntary disclosure of financial information. Companies from some industries may prefer to use IAS or US GAAP, because of specific provisions that cannot be found in local or EU accounting regulation. For example, IAS obliges companies to capitalise internally generated intangibles, whereas the EU Directives allow this. Another difference arises with regard to the valuation of financial instruments, where IAS and US GAAP rules conflict with EU Directives. To control for possible industry effects in the choice of accounting policies, we make a distinction between manufacturing and non-manufacturing firms in the regression analyses. 
$H_{6}$ : The probability of using non-local US GAAP is related to the industry membership of a firm.

\section{RESEARCH DESIGN}

\section{Initial selection procedure}

In this study we attempt to use an as large as possible number of companies from the EU member states using non-local GAAP in the preparation of their financial statements. The selection procedure is as follows. Based on a number of sources (described below) initial groups of listed EU companies possibly using IAS and US GAAP are formed. To be included in this initial group the companies have to appear on the Worldscope database (December 2000 version). For the companies in the initial group we subsequently verify that they are actually stating compliance with non-local GAAP by inspecting the notes and the audit report contained in the annual reports. For each company the annual report of the first fiscal year starting on or after July 1, 1998 (the 1999 annual report) is inspected, because IAS 1 stipulates that from this date on:

'An enterprise whose financial statements comply with International Accounting Standards should disclose that fact. Financial statements should not be described as complying with International Accounting Standards unless they comply with all the requirements of each applicable Standard and each applicable Interpretation of the Standing Interpretations Committee.' (Emphasis added.)

Therefore, if a company refers to the use of IAS in its annual report, it is effectively stating compliance with all applicable standards and interpretations. Consistently, we inspect the annual reports of possible US GAAP adopters for the same period. 


\section{Initial group of companies possibly using IAS}

Italian companies were left out of the initial group of companies possibly using IAS, because they are known to frequently refer to IAS in the absence of local standards, without fully complying with IAS (Zambon, 1998: 572). ${ }^{3}$ However, for three Italian companies previously identified as complying with IAS, of which only two are on the Worldscope database, IAS compliance is verified.

Several data sources were combined in an attempt to identify the initial group of companies in the EU possibly using IAS. First, a list of 'Companies referring to their use of IAS', dated May 2000, was obtained from the IASC. ${ }^{4}$ This list identifies 239 companies domiciled in one of the EU member states (excluding Italy). A similar, but updated list was downloaded from the IASC website in February 2001 (IASC, 2001). This list contains $80 \mathrm{EU}$ companies that published annual reports in 1999/2000 that fully comply with IAS. ${ }^{5}$ In addition we searched two financial statement databases for listed companies using IAS. We searched the Worldscope database (December 2000 version) for EU companies using 'international standards' or 'local standards with some IASC guidelines ${ }^{6}$ as their accounting standards. This search returned 172 (non-Italian) companies. We also used COMPUSTAT's Global Vantage database (May 2001 version) to search for EU companies (again excluding Italy) using accounting standards ${ }^{7}$ 'generally in accordance with IASC guidelines' and 'generally in accordance with IASC and OECD guidelines'. Global Vantage returned 224 companies. We also checked the 165 companies referring to IAS in their 1999 financial statements that are included in the sample of a survey by Cairns (2000). Of these companies 79 are domiciled in one of the EU member states (excluding Italy). Combining these sources and screening for presence of these companies on the Worldscope database resulted in 360 companies being included in the initial group (see table 1, panel A). ${ }^{8}$ 
[Table 1]

Initial group of companies possibly using US GAAP

A similar procedure was undertaken to form an initial group of companies possibly using US GAAP. The two financial statement databases described in the previous section (Worldscope and Global Vantage) were used to identify EU companies that use US GAAP in their 1999 financial statements. Worldscope included 71 companies using 'US GAAP' or 'US GAAP reclassified from other standards'. Global Vantage listed 139 companies using either 'United States' standards', 'domestic standards generally in accordance with United States GAAP', or 'domestic standards generally in accordance with principles generally accepted in the United States'. Combining these two lists of companies, again by checking for presence on the Worldscope database, gives an initial group of 163 companies (see table 1, panel B).

\section{Companies using non-local GAAP}

All companies in the initial group of possible IAS (US GAAP) adopters were contacted to obtain their 1999 annual reports. We could not obtain the annual reports of 26 (38) companies because they were taken over, merged with another company, became inactive, were no longer or not yet listed on an exchange in 1999, or did not reply to the information requests. The annual reports of the remaining companies were examined to verify their use of IAS (US GAAP), by inspecting (1) the notes to the financial statements and (2) the audit report. A company was kept in the group of IAS (US GAAP) companies if the notes or the audit report stated full compliance with IAS (US GAAP). The four different ways in which a company can comply with non-local GAAP are described in section 1 of this paper. As can be seen from table 1, we found no disclosure of compliance with IAS (US GAAP) for 139 (31) of the 
verified companies, leaving 195 (96) companies. Because of differing financial reporting regulations in most countries, companies in the financial industries (SIC code 6) were deleted. ${ }^{9}$ Also, companies without a listing in the EU and companies listed on the Neuer Markt segment of the Deutsche Börse were deleted. This leaves only 133 listed non-financial EU companies voluntarily using non-local GAAP (92 IAS and 41 US GAAP adopters).

When analysing the distribution of firms across countries it becomes clear that firms using non-local GAAP are concentrated in specific countries. Most firms using IAS are domiciled in Germany, Austria, or France. Concentrations of US GAAP adopters are found in Germany, France, and The Netherlands. No firms from the United Kingdom, Ireland, Portugal, or Sweden were identified as adopters of non-local GAAP. For the UK and Ireland, a reason for this phenomenon could be the similarity of IAS and US GAAP with UK GAAP or the relatively high quality of the UK accounting standards (Haller, 2002). Companies domiciled in these two countries are therefore not included in the subsequent analyses on the determinants of non-local GAAP adoption. ${ }^{10}$ Also, companies domiciled in Luxembourg are not included, because of unavailability of data on one of the independent variables (quality of accounting standards). Deleting companies with insufficient data available on the Worldscope database leaves 114 non-local GAAP adopters (80 IAS and 34 US GAAP) for further analysis. Table 2 displays the distribution of firms used in the analyses across countries.

[Table 2]

To investigate the determinants of non-local GAAP adoption, all 1679 non-financial companies listed and domiciled in the EU (excluding companies domiciled in the UK, Ireland, and Luxembourg and companies that are listed on the Neuer Markt) that do not use 
IAS or US GAAP and have sufficient data available on the WS database are used as a control group. We use such a large control group to keep the fraction of non-local GAAP adopters close to the 'real' rate of adoption (see Maddala (2001, section 8.3) or, for a discussion in an accounting context, Zmijewski (1984)). The rate of adoption of non-local GAAP in our group of firms is only $6.4 \%$ ( $4.5 \%$ use IAS and $1.9 \%$ use US GAAP, see table 2$)$. This percentage is higher than the true percentage of non-local GAAP adopters, because relatively more local GAAP adopters are deleted due to data unavailability and because we exclude companies from the UK and Ireland.

\section{Method and variables}

The research method to investigate the determinants of non-local GAAP adoption employed in this study is similar to that used in other papers on the subject (e.g. Ashbaugh, 2001). In a logistic regression a binary variable indicating whether a firm is using local or non-local GAAP is regressed on a number of explanatory variables representing firm- and countryspecific characteristics expected to influence non-local GAAP adoption. The logistic regression model that is estimated is:

$$
\begin{aligned}
\mathrm{P}(\text { GAAP })= & \beta_{0}+\beta_{1} \mathrm{EU}_{-} \mathrm{EX}_{\mathrm{i}}+\beta_{2} \mathrm{NONEU}_{-} \mathrm{EX}_{\mathrm{i}}+\beta_{3} \mathrm{US}_{-} \mathrm{EX}_{\mathrm{i}}+\beta_{4} \mathrm{EASDAQ}_{\mathrm{i}}+ \\
& \beta_{5} \mathrm{GEO}_{-} \mathrm{SEGM}_{\mathrm{i}}+\beta_{6} \mathrm{Q}_{-} \mathrm{ACC}_{\mathrm{i}}+\beta_{7} \mathrm{IAS}_{-} \mathrm{ALLOW}+\beta_{8} \mathrm{OWN}_{-} \mathrm{CONC}_{\mathrm{i}}+ \\
& \beta_{9} \mathrm{DEBT}_{\mathrm{i}}+\beta_{10} \mathrm{MRKT}_{-} \mathrm{CAP}_{\mathrm{i}}+\beta_{11} \mathrm{MFT}_{\mathrm{i}}+\varepsilon_{\mathrm{i}}
\end{aligned}
$$

where GAAP is a dummy variable taking the value 1 if the company uses non-local GAAP, and 0 otherwise. EU_EX represents the number of stock exchange listings of a firm within the EU. Likewise, NONEU_EX is the number of exchange listings outside the EU, excluding the US. US_EX and EASDAQ are dummy variables indicating whether a firm has a US 
exchange listing ${ }^{11}$ or an EASDAQ listing ${ }^{12}$, respectively. GEO_SEGM is the number of geographic segments reported by a firm, and measures the extent of international operations of a firm. Q_ACC is a measure of the quality of a country's accounting standards published by CIFAR (La Porta et al., 1998). Q_ACC is not available for Luxembourg (only 8 observations), which forces us to exclude this country from the analyses (as discussed earlier). IAS_ALLOW is a dummy variable indicating whether a company is domiciled in one of the seven EU member states that explicitly allow usage of IAS for consolidated financial reporting. OWN_CONC and DEBT are measures of the governance structure of a company. The proxy for ownership concentration (OWN_CONC) is a Herfindahl index based on the ownership percentages of the ten largest shareholders of a company. ${ }^{13}$ DEBT is the long-term debt to assets ratio of a company. Size is measured by MRKT_CAP, the natural logarithm of market capitalisation. Industry membership is accounted for by a dummy variable (MFT) representing whether a company is in a manufacturing industry (SIC codes 03). $\varepsilon$ is a randomly distributed error term. The Pearson and Spearman correlations between the independent variables are shown in table 3.

\section{[Table 3]}

\section{RESULTS}

\section{Descriptive statistics and univariate results}

Descriptive statistics and univariate results for the companies included in the analysis can be found in table 4. Wilcoxon two-sample tests indicate that companies using non-local GAAP to draw up their financial statements are more likely to be (1) listed on more (EU and nonEU) exchanges (2), listed in the US, (3) listed on the EASDAQ exchange, (4) operating in a larger number of geographic segments, (5) domiciled in countries with lower quality 
accounting standards, (6) domiciled in countries where IAS is explicitly allowed as an alternative to local GAAP, and (7) larger in terms of market capitalisation. Contrary to expectations, companies using non-local GAAP have a higher ownership concentration and do not differ significantly in terms of their long-term debt to assets ratio. The industry analysis shows no significant difference in the likelihood of non-local GAAP adoption between manufacturing and non-manufacturing companies.

[Table 4]

\section{Logistic regression model}

To test the joint effects of the hypothesised incentives, the logistic regression model described in section 3 (equation (1)) is estimated. The results, displayed in table 5 (model a), show that the choice to adopt non-local instead of local GAAP is significantly positively related to (1) having a listing in the US, (2) being listed on the EASDAQ exchange, (3) operating in more geographic segments, (4) being domiciled in a country that has accounting standards of lower quality, (5) being domiciled in a country that explicitly allows IAS as an alternative to local GAAP, and (6) being larger as measured by market capitalisation. It is remarkable that a company's number of (EU and non-EU) exchange listings is not significantly positively related to non-local GAAP adoption, a finding contrary to the univariate analysis.

[Table 5]

We re-estimate equation (1) without companies listed on the EASDAQ exchange, because these firms have strong incentives to report according to non-local GAAP, 
considering the EASDAQ's obligation to prepare a reconciliation to IAS or US GAAP at least. Dropping the companies listed on the EASDAQ exchange does not materially change the results, as can be seen from table 5 (model b).

To control for possible impediments to non-local GAAP adoption, we drop companies domiciled in countries where IAS is not explicitly allowed as an alternative to local GAAP from the analysis. Again, the results do not change materially (see table 5, model c). However, the positive effect of having a listing in the US disappears. To further address this concern and control for unknown barriers to adoption of non-local GAAP, we re-estimate equation (1) including only firms from countries where we observe a considerable amount of firms (more than 10) adopting non-local GAAP (Austria, France, Germany, and The Netherlands). The logistic regression outcome (not reported) leaves the results reported earlier qualitatively unchanged.

We also run a logistic regression substituting the score developed by Ashbaugh (2001) for the quality of financial accounting in a country, as a measure of the distance between nonlocal and a company's local GAAP. The results (not reported) remain qualitatively unchanged. In addition, we find the hypothesised negative effect of ownership concentration on the likelihood of adoption of non-local GAAP.

\section{Additional analyses}

Considering the requirement for listed EU firms to use IAS for consolidated financial statements from 2005 on, it is particularly interesting to see what factors determine the adoption of IAS versus local GAAP. We therefore repeat the previous analyses and focus on the choice between IAS and local GAAP (excluding companies that report according to US GAAP). The univariate comparison of IAS and local GAAP adopters reported in table 4 gives results largely similar to those above for the comparison of companies using local and 
non-local GAAP. However, companies using IAS are not different from companies using local GAAP with respect to the chances of having a US exchange listing. This is understandable, because the likelihood of adoption of IAS is not expected to be higher for companies listed on a US stock exchange. Furthermore, companies adopting IAS are more likely to be in a manufacturing industry than companies using local GAAP.

We also estimate the logistic regression model (1), with the dependent variable taking the value 1 if a company uses IAS and 0 if a company uses local GAAP. Also, the dummy variable indicating a listing in the US is dropped, because we do not hypothesise that a listing in the US affects the chances of IAS or local GAAP adoption. The results, displayed in table 6 (model a), indicate that the characteristics of companies adopting IAS are similar to those of companies adopting non-local GAAP in general (including US GAAP). Again, dropping companies listed on the EASDAQ exchange (model b) or domiciled outside the seven EU member states that explicitly allow IAS (model c) does not materially influence the results.

[Table 6]

\section{DISCUSSION AND CONCLUDING REMARKS}

We find that the rate of adoption of non-local GAAP by non-financial companies domiciled and listed in the EU in 1999 is relatively low. This means that for a large majority of companies, the benefits of using non-local accounting standards do not seem to outweigh the costs of full compliance. Apparently, voluntary adoption of non-local GAAP brings no economic benefits for a large majority of companies.

In section 4 we analyse the factors associated with adoption of non-local GAAP. We find that the probability of using non-local GAAP increases significantly for companies that are listed on a US exchange. Companies listed on US exchanges are expected to benefit from 
adoption of US GAAP because of SEC requirements to at least prepare a reconciliation to US GAAP. Also, companies listed on the EASDAQ exchange are more likely to report according to non-local GAAP. This can be explained because the exchange requires listed firms to at least prepare a reconciliation to either IAS or US GAAP. We also find that chances of using non-local GAAP increase with the geographic spread of a company's operations. Firms operating internationally benefit more from using non-local GAAP, because they can standardise the information provided to diverse groups of stakeholders. We further find that companies adopting non-local GAAP are more likely to be domiciled in countries with accounting standards of lower quality. Low quality domestic accounting standards induce companies to voluntarily report according to a higher quality set of accounting standards to reflect their commitment to high-quality financial reporting. Furthermore, we find that the likelihood of non-local GAAP use increases for companies that are domiciled in one of seven EU countries where IAS is explicitly allowed as an alternative to local GAAP. Also, companies reporting according to non-local GAAP are larger than companies using local GAAP. Various explanations have been offered in the voluntary disclosure literature, including higher political costs and lower relative information dissemination costs.

We do not find evidence that the corporate governance structure influences non-local GAAP adoption significantly. This could be due to the difficulty of measuring the 'inside' or 'outside' ownership of a company. Two imperfect proxies for the governance structure were used in this paper: (1) leverage and (2) stock ownership concentration. Use of the first variable as a proxy rests on the assumption that equity financing results in more 'outside' ownership than debt financing. Because this need not be the case, we use stock ownership concentration as an additional variable. Besides from this being an imperfect proxy as well, we also had difficulty in interpreting ownership information on the Worldscope (WS) database. When WS indicates that there is no ownership information available, we made the 
crude assumption that there were no large shareholders in the company. Further research could try to measure the effect of corporate governance on choice of accounting standards more accurately. In the multivariate analyses, we also fail to find any evidence that the number of (EU and non-EU) exchange listings influences non-local GAAP adoption significantly. In the univariate analyses we do observe that companies using non-local GAAP have more exchange listings on average.

We also compare companies using IAS with companies using local GAAP. The analysis shows that the factors increasing the probability of reporting according to IAS are the same (except for the effect of a US exchange listing) as those reported for the choice between local and non-local GAAP.

Overall, the results of this study suggest that the net-benefits of voluntary non-local GAAP adoption are positive for only a small fraction of listed EU companies. This is perhaps surprising, and certainly informative, especially considering the obligation for listed EU companies to use IAS from 2005 on.

\section{NOTES}

${ }^{1}$ For an overview of listing requirements of EU stock exchanges, see Haller (2002).

${ }^{2}$ They also find that in market-oriented financial systems, private sector bodies are more involved in accounting standard setting, accounting practices follow the British-American model, as opposed to the Continental-European model, tax rules have less influence on financial reporting, and spending on auditing services is relatively high.

${ }^{3}$ Private communication with Stefano Zambon confirmed this. His research shows that only three Italian companies comply fully with IAS. 
${ }^{4}$ The authors would like to thank Paul Pacter of the IASC for providing the list that was no longer available from the IASC website.

${ }^{5}$ To be included, the auditor's report and summary of accounting policies, or footnotes must state that the financial statements comply with IAS without qualification (IASC, 2001).

${ }^{6}$ Not necessarily IAS, however no more specific data was available.

${ }^{7}$ Item number GF66: Accounting standard - Note (ASTD). Here also, no more specific data was available.

${ }^{8}$ There was considerable overlap between the different data sources.

${ }^{9}$ We also excluded the small number of companies indicated as being in the SIC code 9 category.

${ }^{10}$ The inclusion of companies domiciled in the United Kingdom in our regression analyses (we do not have data on the quality of Irish accounting standards) does not materially influence the results.

${ }^{11}$ Information from the Worldscope database was supplemented with data from the NYSE (www.nyse.com) and NASDAQ (www.nasdaq.com) exchanges.

${ }^{12}$ Data was obtained from the EASDAQ exchange (www.easdaq.com).

${ }^{13}$ This index is calculated as $\mathrm{H}=\Sigma \mathrm{o}_{\mathrm{i}}{ }^{2}$, where $\mathrm{o}_{\mathrm{i}}$ is the ownership percentage of owner $\mathrm{i}, \mathrm{i} \in$ $[1,10]$. Generally, Worldscope only reports ownership data for shareholders holding more than $5 \%$ of the shares in a company. Very few companies have ten large shareholders.

\section{REFERENCES}

Ali, A. and Hwang, L. (2000) 'Country-specific factors related to the value-relevance of accounting data', Journal of Accounting Research, Vol. 38(1): 1-21.

Ashbaugh, H. (2001). 'Non-US firms' accounting standards choices', Journal of Accounting and Public Policy, Vol. 20(2): 129-53. 
Ashbaugh, H. and Pincus, M. (2001) 'Domestic accounting standards, International Accounting Standards, and the predictability of earnings', Journal of Accounting Research, Vol. 39(3): 417-34.

Biddle, G.C. and Saudagaran, S.M. (1991) 'Foreign stock listings: benefits, costs, and the accounting policy dilemma', Accounting Horizons, Vol. 5(3): 69-80.

Chow, C.W. and Wong-Boren, A. (1987) 'Voluntary financial disclosure by Mexican corporations', The Accounting Review, Vol. 62(3): 533-41.

Commission of the European Communities (1995) 'Accounting harmonisation: a new strategy vis-à-vis international harmonisation', COM 95 (508), Brussels.

Commission of the European Communities (2000) 'Examination of the conformity between International Accounting Standards applicable to accounting periods beginning before 1 July 1999 and the European Accounting Directives', XV/6005/99, Brussels.

Commission of the European Communities (2001a) Financial reporting: the IAS Regulation Frequently Asked Questions, on the Internet as per February 2001 (http://europa.eu.int/comm/internal_market/en/company/account/news/iasfaq.htm).

Commission of the European Communities (2001b) Proposal for a regulation of the European Parliament and of the Council on the application of international accounting standards, COM(2001) 80 final, 2001/0044(COD), Brussels.

Cooke, T.E. (1992) 'The impact of size, stock market listing and industry type on disclosure in the annual reports of Japanese listed corporations', Accounting and Business Research, Vol. 22(87): 229-37.

Dumontier, P. and Raffournier, B. (1998) 'Why firms comply voluntarily with IAS: an empirical analysis with Swiss data', Journal of International Financial Management and Accounting, 9(3): 216-45.

El-Gazzar, S.M., Finn, P.M. and Jacob, R. (1999) 'An empirical investigation of multinational firms' compliance with International Accounting Standards', The International Journal of Accounting, Vol. 34(2): 239-48.

European Parliament and Council (2002) Regulation of the European Parliament and of the Council on the application of international accounting standards, PE-CONS 3626/02 - DRS 28 - CODEC 544 - 2001/0044(COD), Brussels, 27 May.

Fédération des Experts Comptables Européens (1993) Seventh Directive options and their implementation, Fédération des Experts Comptables Européens/Routledge, London.

Foster, G. (1986) Financial statement analysis, $2^{\text {nd }}$ edn. Upper Saddle River, NJ: PrenticeHall.

Haller, A. (2002) 'Financial accounting developments in the European Union: past events and future prospects', European Accounting Review, 11(1): 153-90.

International Accounting Standards Committee (2000) 'Companies referring to their use of IAS', on the Internet as per May 2000 (www.iasc.org.uk).

International Accounting Standards Committee (2001) 'Companies referring to their use of IAS', on the Internet as per February 2001 (www.iasc.org.uk).

International Organisation of Securities Commissions (2000) 'IASC standards - assessment report', Report of the Technical Committee of the International Organisation of Securities Commissions, May.

Joos, P. and Weets, V. (2000) 'Impact of the introduction of the euro on financial reporting in the EMU', Vierentwintigste Vlaams Wetenschappelijk Economisch Congres, Gent, 17-18 March.

La Porta, R., Lopez-de-Silanes, F.L. and Shleifer, A. (1998) 'Law and finance', Journal of Political Economy, Vol. 106(6): 1113-55. 
Lang, M. and Lundholm, R. (1993) 'Cross-sectional determinants of analyst ratings of corporate disclosures', Journal of Accounting Research, Vol. 31(2): 246-71.

Leuz, C. and Verrecchia, R. (2000) 'The economic consequences of increased disclosure', Journal of Accounting Research, Vol. 38(supplement): 91-124.

Leuz, C. (2001) 'IAS versus US GAAP: A 'New Market' based comparison', Working paper, University of Pennsylvania, June 2001.

Maddala, G. (2001) Introduction to econometrics, $3^{\text {rd }}$ edn. New York: John Wiley \& Sons.

Meek, G.K., Roberts, C.B. and Gray, S.J. (1995) 'Factors influencing voluntary annual report disclosures by U.S., U.K. and continental European multinational corporations', Journal of International Business Studies, Vol. 26(3): 555-72.

Murphy, A.B. (1999) 'Firm characteristics of Swiss companies that utilize International Accounting Standards', International Journal of Accounting, Vol. 35(1): 121-31.

Nobes, C. and Parker, R. (1998) Comparative international accounting, $5^{\text {th }}$ edn. London: Prentice-Hall Europe.

Saudagaran, S.M. and Biddle, G.C. (1995) 'Foreign listing location: a study of MNCs and stock exchanges in eight countries', Journal of International Business Studies, Vol. 26(2): 319-41.

Street, D.L., Gray, S.J. and Bryant, S.M. (1999) 'Acceptance and observance of International Accounting Standards: an empirical study of companies claiming to comply with IASs', The International Journal of Accounting, Vol. 34(1): 11-48.

Street, D.L. and Bryant, S.M. (2000) 'Disclosure level and compliance with IAS: a comparison of companies with and without U.S. listings and filings', The International Journal of Accounting, Vol. 35(3): 305-29.

Street, D.L. and Gray, S.J. (2001) 'Observance of International Accounting Standards: factors explaining non-compliance by companies referring to their use of IAS', Paper presented to the $24^{\text {th }}$ Annual Congress of the European Accounting Association, Athens, Greece, 18-20 April.

Zambon, S. (1998) 'Italy', in: Alexander, D. and Archer, S. (eds.) European Accounting Guide, $3^{\text {rd }}$ edn. San Diego/London: Harcourt Brace \& Company, pp. 523-669.

Zarzeski, M.T. (1996) 'Spontaneous harmonization effects of culture and market forces on accounting disclosure practices', Accounting Horizons, Vol. 10(1): 18-37.

Zmijewski, M. (1984) 'Methodological issues related to the estimation of financial distress prediction models', Journal of Accounting Research, Vol.22(supplement): 59-82. 
Table 1: Identification process of companies adopting non-local GAAP

Panel A: Companies using IAS

\begin{tabular}{|c|c|c|}
\hline Source & $\begin{array}{l}\text { Number of } \\
\text { companies }\end{array}$ & $\begin{array}{r}\text { Companies on WS } \\
\text { database }\end{array}$ \\
\hline IASC list May 2000 & 239 & 216 \\
\hline IASC list February 2001 & 80 & 74 \\
\hline Worldscope (WS) database & 172 & 172 \\
\hline Global Vantage (GV) database & 224 & 212 \\
\hline Cairns & 79 & 78 \\
\hline & & 358 \\
\hline Italian companies possibly using IAS & 3 & 2 \\
\hline Group of companies to be verified & & 360 \\
\hline Not verified (taken over, merged, became inactive, no longer or not yet & & (26) \\
\hline listed on an exchange in 1999 , or no reply to information requests) & & \\
\hline No disclosure of compliance with IAS & & $(139)$ \\
\hline Financial companies (SIC code 6 , or unknown) & & $(22)$ \\
\hline Listed on the Neuer Markt segment of the Deutsche Börse & & $(79)$ \\
\hline Not listed on an EU exchange (or unknown) & & (2) \\
\hline Non-financial companies voluntarily disclosing compliance with IAS & & 92 \\
\hline Insufficient data availability $^{*}$ & & $(12)$ \\
\hline IAS adopters used in analyses & & 80 \\
\hline
\end{tabular}

Panel B: Companies using US GAAP

\begin{tabular}{|c|c|c|}
\hline Source & $\begin{array}{l}\text { Number of } \\
\text { companies }\end{array}$ & $\begin{array}{l}\text { Companies on WS } \\
\text { database }\end{array}$ \\
\hline Worldscope (WS) database & 71 & 71 \\
\hline Global Vantage (GV) database & 139 & 133 \\
\hline Group of companies to be verified & & 163 \\
\hline Not verified (taken over, merged, became inactive, no longer or not yet & & (38) \\
\hline listed on an exchange in 1999 , or no reply to information requests) & & (30) \\
\hline No disclosure of compliance with US GAAP & & $(31)$ \\
\hline US GAAP adopters identified using other sources & & 2 \\
\hline Financial companies (SIC code 6 , or unknown) & & (4) \\
\hline Listed on the Neuer Markt segment of the Deutsche Börse & & (46) \\
\hline Not listed on an EU exchange (or unknown) & & $(5)$ \\
\hline Non-financial companies voluntarily disclosing compliance with US GAAP & & 41 \\
\hline Insufficient data availability $^{*}$ & & (7) \\
\hline US GAAP adopters used in analyses & & 34 \\
\hline
\end{tabular}


Table 2: Distribution of companies by country of domicile*

\begin{tabular}{|c|c|c|c|c|c|c|c|c|}
\hline \multirow[b]{2}{*}{ Country } & \multicolumn{2}{|c|}{ IAS } & \multicolumn{2}{|c|}{ US GAAP } & \multicolumn{2}{|c|}{$\begin{array}{l}\text { Non-local GAAP } \\
\text { (IAS/US GAAP) }\end{array}$} & \multicolumn{2}{|c|}{ Local GAAP } \\
\hline & $n$ & $\%$ & $n$ & $\%$ & $n$ & $\%$ & $n$ & $\%$ \\
\hline Austria & 16 & $20.0 \%$ & 1 & $2.9 \%$ & 17 & $14.9 \%$ & 35 & $2.1 \%$ \\
\hline Belgium & 4 & $5.0 \%$ & 1 & $2.9 \%$ & 5 & $4.4 \%$ & 83 & $4.9 \%$ \\
\hline Denmark & 7 & $8.8 \%$ & 1 & $2.9 \%$ & 8 & $7.0 \%$ & 98 & 5.85 \\
\hline Finland & 2 & $2.5 \%$ & 0 & $0.0 \%$ & 2 & $1.8 \%$ & 105 & $6.3 \%$ \\
\hline France & 11 & $13.8 \%$ & 12 & $35.3 \%$ & 23 & $20.2 \%$ & 460 & $27.4 \%$ \\
\hline Germany & 35 & $43.8 \%$ & 8 & $23.5 \%$ & 43 & $36.0 \%$ & 245 & $14.6 \%$ \\
\hline Greece & 2 & $2.5 \%$ & 0 & $0.0 \%$ & 2 & $1.8 \%$ & 119 & $7.1 \%$ \\
\hline Italy & 1 & $1.3 \%$ & 0 & $0.0 \%$ & 1 & $0.9 \%$ & 120 & $7.1 \%$ \\
\hline The Netherlands & 1 & $1.3 \%$ & 11 & $32.4 \%$ & 12 & $10.5 \%$ & 140 & $8.3 \%$ \\
\hline Portugal & 0 & $0.0 \%$ & 0 & $0.0 \%$ & 0 & $0.0 \%$ & 23 & $1.4 \%$ \\
\hline Spain & 1 & $1.3 \%$ & 0 & $0.0 \%$ & 1 & $0.9 \%$ & 67 & $4.0 \%$ \\
\hline Sweden & 0 & $0.0 \%$ & 0 & $0.0 \%$ & 0 & $0.0 \%$ & 184 & $11.0 \%$ \\
\hline Total & 80 & $100 \%$ & 34 & $100 \%$ & 114 & $100 \%$ & 1679 & $100 \%$ \\
\hline Adoption \% & \multicolumn{2}{|c|}{$4.5 \%$} & \multicolumn{2}{|c|}{$1.9 \%$} & \multicolumn{2}{|c|}{$6.4 \%$} & \multicolumn{2}{|c|}{$93.6 \%$} \\
\hline
\end{tabular}

Only cases with full data available for analyses are tabulated. Companies from the UK and Ireland are excluded because of the comparable high quality of UK GAAP and the non-local GAAPs studied (IAS and US GAAP). Luxembourgian companies are excluded from further analyses, because of unavailability of data on one of the independent regression variables (Q_ACC). 
Table 3: Pearson/Spearman correlations

\begin{tabular}{|c|c|c|c|c|c|c|c|c|c|c|c|}
\hline Variable & EU_EX & NONEU_EX & US_EX & EASDAQ & GEO_SEGM & $\overline{\text { Q_ACC }}$ & IAS_ALLOW & OWN_CONC & DEBT & MRKT_CAP & MFT \\
\hline EU_EX & 1.0000 & $0.6493^{* * *}$ & $0.3125^{* * *}$ & -0.0072 & $0.2259^{* * *}$ & $-0.0602^{* *}$ & $0.0632^{* * *}$ & 0.0118 & 0.0128 & $0.3696^{* * *}$ & $0.0969^{* * *}$ \\
\hline NONEU_EX & $0.3725^{* * * *}$ & 1.0000 & $0.2460^{* * *}$ & -0.0137 & $0.1968^{* * *}$ & 0.0039 & 0.0053 & -0.0216 & 0.0025 & $0.2802^{* * *}$ & $0.0686^{* * *}$ \\
\hline US_EX & $0.2081^{* * *}$ & $0.2477^{* * *}$ & 1.0000 & -0.0201 & $0.1639^{* * *}$ & 0.0309 & $-0.0624^{* * *}$ & $-0.0456^{*}$ & $0.0593^{* *}$ & $0.3739^{* * * *}$ & -0.0023 \\
\hline EASDAQ & 0.0011 & -0.0143 & -0.0201 & 1.0000 & $-0.0629^{* * *}$ & $-0.0658^{* * * *}$ & $0.0473^{* *}$ & $-0.0625^{* * *}$ & -0.0297 & -0.0337 & -0.0348 \\
\hline GEO_SEGM & $0.2194^{* * * *}$ & $0.1819^{* * *}$ & $0.1658^{* * *}$ & $-0.0748^{* * * *}$ & 1.0000 & $0.0636^{* * * *}$ & 0.0146 & $0.1177^{* * * *}$ & $0.0654^{* * *}$ & $0.3766^{* * *}$ & $0.2059^{* * *}$ \\
\hline Q_ACC & $-0.1335^{* * * *}$ & -0.0166 & $0.0583^{* * *}$ & $-0.0939^{* * * *}$ & 0.0231 & 1.0000 & -0.0252 & $-0.1593^{* * * *}$ & $0.1099^{* * *}$ & $-0.0799^{* * *}$ & $-0.1021^{* * * *}$ \\
\hline IAS_ALLOW & $0.1133^{* * *}$ & 0.0123 & $-0.0624^{* * *}$ & $0.0473^{* *}$ & 0.0360 & -0.0016 & 1.0000 & $0.1695^{* * *}$ & 0.0181 & -0.0312 & $0.0564^{* *}$ \\
\hline OWN_CONC & $0.1001^{* * *}$ & 0.0200 & 0.0131 & $-0.1042^{* * *}$ & $0.3986^{* * *}$ & $-0.1009^{* * * *}$ & ${ }^{* * *} 0.0716$ & 1.0000 & -0.0372 & $0.0889^{* * * *}$ & $0.0809^{* * * *}$ \\
\hline DEBT & 0.0196 & 0.0313 & $0.0658^{* * *}$ & -0.0276 & $0.1329^{* * *}$ & $0.1122^{* * *}$ & $0.0631^{* * *}$ & 0.0385 & 1.0000 & $0.0409^{*}$ & -0.0358 \\
\hline MRKT_CAP & $0.2755^{* * *}$ & $0.2172^{* * * *}$ & $0.2802^{* * *}$ & -0.0331 & $0.3689^{* * * *}$ & $-0.1046^{* * *}$ & $-0.0470^{* *}$ & $0.2243^{* * * *}$ & $0.0429^{*}$ & 1.0000 & $-0.0406^{*}$ \\
\hline MFT & $0.0957^{* * * *}$ & $0.0652^{* * *}$ & -0.0023 & -0.0348 & $0.2273^{* * *}$ & $-0.1354^{* * * *}$ & $0.0564^{* *}$ & $0.1181^{* * * *}$ & 0.0312 & $-0.0446^{* *}$ & 1.0000 \\
\hline
\end{tabular}

Pearson (Spearman) correlations are displayed in the upper (lower) part of the correlation matrix, above (below) the diagonal.

*** ${ }^{* *},{ }^{*}$ Significant Spearman (Pearson) correlations at significance levels of 0.01, 0.05, and 0.10 respectively.

EU_EX is the number of exchange listings of a company within the EU, NONEU_EX is the number of exchange listings of a company outside the EU, excluding the US, US_EX is a dummy variable indicating whether a company is listed on a US exchange, EASDAQ is a dummy variable indicating whether a company is listed on the EASDAQ exchange, GEO_SEGM is the number of geographic segments reported by a company, Q_ACC is a score developed by CIFAR measuring the quality of a country's accounting standards, IAS_ALLOW is a dummy variable indicating whether IAS is explicitly allowed as an alternative to local GAAP in a country, OWN_CONC is a Herfindahl index measuring a company's stock ownership concentration, DEBT is a company's long-term debt to assets ration, MRKT_CAP is the natural logarithm of a company's market capitalisation, MFT is a dummy variable indicating whether a company is operating in a manufacturing industry. 
Table 4: Descriptive statistics and univariate results

\begin{tabular}{|c|c|c|c|c|c|c|c|c|c|c|c|c|c|c|c|}
\hline \multirow[b]{2}{*}{ Variable } & \multicolumn{3}{|c|}{$\begin{array}{c}\text { IAS } \\
(\mathrm{n}=80)\end{array}$} & \multicolumn{3}{|c|}{$\begin{array}{l}\text { US GAAP } \\
\qquad(\mathrm{n}=34)\end{array}$} & \multicolumn{3}{|c|}{$\begin{array}{c}\text { Non-local GAAP } \\
\text { (IAS/US GAAP) } \\
(\mathrm{n}=114)\end{array}$} & \multicolumn{3}{|c|}{$\begin{array}{l}\text { Local GAAP } \\
\qquad(\mathrm{n}=1679)\end{array}$} & \multicolumn{3}{|c|}{$\begin{array}{c}\text { Total } \\
(n=1793)\end{array}$} \\
\hline & Mean & $\begin{array}{c}\text { St. } \\
\text { Dev. }\end{array}$ & Med. & Mean & $\begin{array}{c}\text { St. } \\
\text { Dev. }\end{array}$ & Med. & Mean & $\begin{array}{c}\text { St. } \\
\text { Dev. }\end{array}$ & Med. & Mean & $\begin{array}{c}\text { St. } \\
\text { Dev. }\end{array}$ & Med. & Mean & $\begin{array}{c}\text { St. } \\
\text { Dev. }\end{array}$ & Med. \\
\hline EU_EX & $1.4625^{* * * *}$ & 0.8104 & 1.0000 & 1.5882 & 1.0185 & 1.0000 & $1.5000^{* * * *}$ & 0.8749 & 1.0000 & 1.1453 & 0.5295 & 1.0000 & 1.1679 & 0.5642 & 1.0000 \\
\hline NONEU_EX & $0.1375^{* * *}$ & 0.4967 & 0.0000 & 0.1765 & 0.5205 & 0.0000 & $0.1491^{* * *}$ & 0.5019 & 0.0000 & 0.0328 & 0.2551 & 0.0000 & 0.0402 & 0.2786 & 0.0000 \\
\hline US_EX & 0.0375 & 0.1912 & 0.0000 & 0.5000 & 0.5075 & 0.5000 & $0.1754^{* * *}$ & 0.3820 & 0.0000 & 0.0339 & 0.1812 & 0.0000 & 0.0429 & 0.2028 & 0.0000 \\
\hline EASDAQ & $0.0750^{* * * *}$ & 0.2651 & 0.0000 & 0.0882 & 0.2879 & 0.0000 & $0.0789^{* * * *}$ & 0.2708 & 0.0000 & 0.0042 & 0.0645 & 0.0000 & 0.0089 & 0.0941 & 0.0000 \\
\hline GEO_SEGM & $3.8875^{* * *}$ & 2.1932 & 4.0000 & 4.0294 & 1.8827 & 4.0000 & $3.9298^{* * * *}$ & 2.0981 & 4.0000 & 2.5408 & 2.1520 & 1.0000 & 2.6291 & 2.1746 & 1.0000 \\
\hline Q_ACC & $61.5625^{* * *}$ & 5.1652 & 62.0000 & 64.8529 & 3.5687 & 64.0000 & $62.5439^{* * *}$ & 4.9656 & 62.0000 & 66.3353 & 8.4665 & 64.0000 & 66.0943 & 8.3386 & 64.0000 \\
\hline IAS_ALLOW & $0.8625^{* * * *}$ & 0.3465 & 1.0000 & 0.6471 & 0.4851 & 1.0000 & $0.7982^{* * * *}$ & 0.4031 & 1.0000 & 0.6242 & 0.4845 & 1.0000 & 0.6352 & 0.4815 & 1.0000 \\
\hline OWN_CONC & $0.1817^{++}$ & 0.2322 & 0.1032 & 0.1117 & 0.1529 & 0.0472 & $0.1608^{++}$ & 0.2135 & 0.0883 & 0.1432 & 0.2195 & 0.0232 & 0.1443 & 0.2191 & 0.0256 \\
\hline DEBT & 0.1180 & 0.1162 & 0.0953 & 0.1616 & 0.1610 & 0.1327 & 0.1310 & 0.1319 & 0.0978 & 0.1286 & 0.1253 & 0.0971 & 0.1288 & 0.1257 & 0.0972 \\
\hline MRKT_CAP & $6.6125^{* * * *}$ & 2.0580 & 6.3842 & 7.4052 & 2.1497 & 7.0748 & $6.8489^{* * * *}$ & 2.1079 & 6.7201 & 5.1946 & 1.9506 & 5.0342 & 5.2998 & 2.0015 & 5.1190 \\
\hline MFI & $0.7125^{+++}$ & 0.4555 & 1.0000 & 0.6176 & 0.4933 & 1.0000 & 0.6842 & 0.4669 & 1.0000 & 0.6111 & 0.4877 & 1.0000 & 0.6157 & 0.4866 & 1.0000 \\
\hline
\end{tabular}

******* A one-sided Wilcoxon rank sum test rejects the hypothesis of no difference in the distribution of the variable across companies adopting IAS ('IAS' column) or nonlocal GAAP ('Non-local GAAP' column) and local GAAP at significance levels of $0.01,0.05$, and 0.10 respectively.

${ }^{+++},{ }^{++},{ }^{+}$A two-sided Wilcoxon rank sum test rejects the hypothesis of no difference in the distribution of the variable across companies adopting IAS ('IAS' column) or nonlocal GAAP ('Non-local GAAP' column) and local GAAP at significance levels of $0.01,0.05$, and 0.10 respectively.

EU_EX is the number of exchange listings of a company within the EU, NONEU_EX is the number of exchange listings of a company outside the EU, excluding the US, US_EX is a dummy variable indicating whether a company is listed on a US exchange, EASDAQ is a dummy variable indicating whether a company is listed on the EASDAQ exchange, GEO_SEGM is the number of geographic segments reported by a company, Q_ACC is a score developed by CIFAR measuring the quality of a country's accounting standards, IAS_ALLOW is a dummy variable indicating whether IAS is explicitly allowed as an alternative to local GAAP in a country, OWN_CONC is a Herfindahl index measuring a company's stock ownership concentration, DEBT is a company's long-term debt to assets ration, MRKT_CAP is the natural logarithm of a company's market capitalisation, MFT is a dummy variable indicating whether a company is operating in a manufacturing industry. 
Table 5: Logistic regression results: Non-local GAAP versus local GAAP

$\mathrm{P}(\mathrm{GAAP})=\beta_{0}+\beta_{1} \mathrm{EU}_{-} \mathrm{EX}_{\mathrm{i}}+\beta_{2} \mathrm{NONEU} \_\mathrm{EX}_{\mathrm{i}}+\beta_{3} \mathrm{US}_{-} \mathrm{EX}_{\mathrm{i}}+\beta_{4} \mathrm{EASDAQ}_{\mathrm{i}}+\beta_{5} \mathrm{GEO}_{-} \mathrm{SEG}_{\mathrm{i}}+\beta_{6} \mathrm{Q} \_\mathrm{ACC}_{\mathrm{i}}+\beta_{7} \mathrm{IAS}_{-} \mathrm{ALLOW}+\beta_{8} \mathrm{OWN} \_\mathrm{CONC} \mathrm{i}_{\mathrm{i}}+\beta_{9} \mathrm{DEBT}_{\mathrm{i}}+$ $\beta_{10}$ MRKT_CAP $_{\mathrm{i}}+\beta_{11} \mathrm{MFT}_{\mathrm{i}}+\varepsilon_{\mathrm{i}}$

\begin{tabular}{|c|c|c|c|c|c|c|c|}
\hline \multirow[b]{2}{*}{ Independent variable } & \multirow[b]{2}{*}{ Expected sign } & \multicolumn{2}{|c|}{ Model (a) } & \multicolumn{2}{|c|}{ Model (b) } & \multicolumn{2}{|c|}{ Model (c) } \\
\hline & & Coefficient & Standard error & Coefficient & Standard error & Coefficient & Standard error \\
\hline Intercept & & -1.2015 & 1.0093 & -1.1355 & 1.0216 & $3.1725^{+}$ & 1.6723 \\
\hline EU_EX & + & 0.0921 & 0.1680 & 0.0778 & 0.1697 & 0.0936 & 0.1876 \\
\hline NONEU_EX & + & -0.2073 & 0.3198 & -0.1830 & 0.3206 & -0.1453 & 0.3391 \\
\hline US_EX & + & $1.0159^{* * *}$ & 0.3637 & $1.0310^{* * *}$ & 0.3644 & 0.5764 & 0.4729 \\
\hline EASDAQ & + & $3.4783^{* * *}$ & 0.5710 & - & - & $3.1263^{* * * *}$ & 0.6171 \\
\hline GEO_SEGM & + & $0.1877^{* * *}$ & 0.0480 & $0.1973^{* * *}$ & 0.0481 & $0.1764^{* * * *}$ & 0.0580 \\
\hline Q_ACC & - & $-0.0771^{* * *}$ & 0.0152 & $-0.0770^{* * *}$ & 0.0154 & $-0.1301^{* * *}$ & 0.0258 \\
\hline IAS_ALLOW & + & $1.0756^{* * *}$ & 0.2745 & $1.1108^{* * *}$ & 0.2805 & - & - \\
\hline OWN_CONC & - & -0.1864 & 0.4759 & -0.1882 & 0.4763 & -0.1536 & 0.4935 \\
\hline DEBT & - & -0.1240 & 0.9210 & -0.2429 & 0.9336 & -0.6144 & 1.1154 \\
\hline MRKT_CAP & + & $0.2822^{* * *}$ & 0.0636 & $0.2767^{* * *}$ & 0.0640 & $0.3065^{* * * *}$ & 0.0739 \\
\hline MFT & & 0.2108 & 0.2433 & 0.1110 & 0.2472 & 0.2875 & 0.2882 \\
\hline Likelihood ratio $\chi^{2}$ & & 167.9951 & & 137.8629 & & 124.5025 & \\
\hline
\end{tabular}

${ }^{* * * * * *},{ }^{*}$ Significantly different from zero (one-sided) at levels of $0.01,0.05$, and 0.10 respectively.

${ }^{+++},{ }^{++},{ }^{+}$Significantly different from zero (two-sided) at levels of $0.01,0.05$, and 0.10 respectively.

$\mathrm{P}(\mathrm{GAAP})$ is the probability of using non-local (1) versus local GAAP (0), EU_EX is the number of exchange listings of a company within the EU, NONEU_EX is the number of exchange listings of a company outside the EU, excluding the US, US_EX is a dummy variable indicating whether a company is listed on a US exchange, EASDAQ is a dummy variable indicating whether a company is listed on the EASDAQ exchange, GEO_SEGM is the number of geographic segments reported by a company, Q_ACC is a score developed by CIFAR measuring the quality of a country's accounting standards, IAS_ALLOW is a dummy variable indicating whether IAS is explicitly allowed as an alternative to local GAAP in a country, OWN_CONC is a Herfindahl index measuring a company's stock ownership concentration, DEBT is a company's long-term debt to assets ration, MRKT_CAP is the natural logarithm of a company's market capitalisation, MFT is a dummy variable indicating whether a company is operating in a manufacturing industry. 


\section{Table 6: Logistic regression results: IAS versus local GAAP}

$\mathrm{P}(\mathrm{IAS})=\beta_{0}+\beta_{1} \mathrm{EU}_{-} \mathrm{EX}_{\mathrm{i}}+\beta_{2} \mathrm{NONEU}_{-} \mathrm{EX}_{\mathrm{i}}+\beta_{3} \mathrm{EASDAQ}_{\mathrm{i}}+\beta_{4} \mathrm{GEO}_{-} \mathrm{SEG}_{\mathrm{i}}+\beta_{5} \mathrm{Q} \_\mathrm{ACC}_{\mathrm{i}}+\beta_{6} \mathrm{IAS}_{-} \mathrm{ALLOW}+\beta_{7} \mathrm{OWN}_{-} \mathrm{CONC} \mathrm{i}_{\mathrm{i}}+\beta_{8} \mathrm{DEBT} \mathrm{T}_{\mathrm{i}}+\beta_{9} \mathrm{MRKT}_{-} \mathrm{CAP} \mathrm{P}_{\mathrm{i}}+\beta_{10} \mathrm{MFT}_{\mathrm{i}}+\varepsilon_{\mathrm{i}}$

\begin{tabular}{|c|c|c|c|c|c|c|c|}
\hline \multirow[b]{2}{*}{ Independent variable } & \multirow[b]{2}{*}{ Expected sign } & \multicolumn{2}{|c|}{ Model (a) } & \multicolumn{2}{|c|}{ Model (b) } & \multicolumn{2}{|c|}{ Model (c) } \\
\hline & & Coefficient & Standard error & Coefficient & Standard error & Coefficient & Standard error \\
\hline Intercept & & -0.4969 & 1.1603 & -0.6392 & 1.1692 & $5.2712^{+++}$ & 1.9178 \\
\hline EU_EX & + & 0.1044 & 0.1950 & 0.1005 & 0.1960 & 0.0995 & 0.2072 \\
\hline NONEU_EX & + & -0.2095 & 0.3673 & -0.1954 & 0.3674 & -0.1365 & 0.3799 \\
\hline EASDAQ & + & $3.0381^{* * *}$ & 0.6434 & - & - & $2.8304^{* * * *}$ & 0.6769 \\
\hline GEO_SEGM & + & $0.1760^{* * *}$ & 0.0568 & $0.1870^{* * *}$ & 0.0568 & $0.1525^{* * *}$ & 0.0649 \\
\hline Q_ACC & - & $-0.1014^{* * *}$ & 0.0189 & $-0.0970^{* * *}$ & 0.0189 & $-0.1681^{* * *}$ & 0.0306 \\
\hline IAS_ALLOW & + & $1.6287^{* * *}$ & 0.3865 & $1.5802^{* * *}$ & 0.3832 & - & - \\
\hline OWN_CONC & - & -0.1264 & 0.5113 & -0.0994 & 0.5117 & 0.0401 & 0.5251 \\
\hline DEBT & - & -1.0050 & 1.1416 & -1.0215 & 1.1517 & -0.5745 & 1.2487 \\
\hline MRKT_CAP & + & $0.3129^{* * *}$ & 0.0706 & $0.3073^{* * *}$ & 0.0709 & $0.3132^{* * * *}$ & 0.0810 \\
\hline MFT & & 0.2719 & 0.2879 & 0.1358 & 0.2916 & 0.3418 & 0.3288 \\
\hline Likelihood ratio $\chi^{2}$ & & 125.9943 & & 102.2051 & & 101.8378 & \\
\hline
\end{tabular}

****** Significantly different from zero (one-sided) at levels of $0.01,0.05$, and 0.10 respectively.

${ }^{+++},++,+$Significantly different from zero (two-sided) at levels of $0.01,0.05$, and 0.10 respectively.

P(IAS) is the probability of using IAS (1) versus local GAAP (0), EU_EX is the number of exchange listings of a company within the EU, NONEU_EX is the number of exchange listings of a company outside the EU, excluding the US, US_EX is a dummy variable indicating whether a company is listed on a US exchange, EASDAQ is a dummy variable indicating whether a company is listed on the EASDAQ exchange, GEO_SEGM is the number of geographic segments reported by a company, Q_ACC is a 